\title{
A Portrait of a Princes in Society in Morton's Diana: Her True Story - In Her Own Words (A Biographical Analysis)
}

\author{
Sagita K. Mangolo
}

\begin{abstract}
The purpose of this research is to reveal about Princess Diana's role in society in Andrew Morton Diana: Her True Story - In Her Own Words. This research is classified as a qualitative research. The data gathered are in the form of words as well as quotation. The writer collects the data from two kinds of sources namely primary source and secondary. The primary data source was taken from the Biography book Diana: Her True Story - In Her Own Words by Andrew Morton. And the secondary source is other material that supports the analysis, such as website. The result of this study shows the role of Princess Diana in society. Diana as a Princess actives in humanitarian activities, she was always seen visit and entertain AIDS sufferers, leprosy and other diseases, she also actively visited homeless people in shelters, she was active in supporting human welfare, and actively raised funds and formed charities to help people who need help. The one thing that Diana had done that shocked the world at the time was when she broke the stigma about Aids, that touching or shaking hands with people with Aids would get infected, but Diana shook their hands and even sat close and comforted them. Besides that which is not less great than that, Diana shakes hands with lepers without gloves. Diana also bravely walked in the area that was landed by landmines in protest of landmines in Angola. Diana also often entertained friends who were in grief. Even though the princess was gone but the legacy that she gave to her children, worthy lessons about the life she taught in her children made them follow in her mother's footsteps so Diana's role in society remains until now.
\end{abstract}

\section{Keywords: Biography, Humanitarian, Princess, Lady Diana, Biographical Approach.}

\section{INTRODUCTION}

Halleman (2017) "A princess is daughter of royal family or the British sovereign, or wife of prince". Become a royal family is the dream of every human. Especially for every girl have a dream to become a princess or a prince's wife. The Kingdom palace, prince charm, crown over heads, expensive dresses, expensive jewelries, expensive vehicles and bodyguards cannot be separated either from a princess.

United Kingdom is the greatest kingdom that governs the British Commonwealth. The kingdom that is now led by Queen Elizabeth II, who has son the next heir to the throne of Britain, Prince Charles. The ears of British people are not necessarily complete if just only hearing the name of Princes Charles if not yet juxtaposed with a name, Diana. She opened the eyes of the world that the life 
of being princess was not as beautiful as imagined and she had something that rarely people have and even not owned by princesses in the world at that time.

Andrew Morton is the author of Diana's Biography. One of his best seller is Diana: Her True Story (1992). Twentyfive years on, biographer Andrew Morton has revisited the secret tapes he and the late Princess made, revealing startling new insights into her life and mind.

According to M.G Maru (2009), "Literature is authentic material. It is true that literary text is not created for the primary purpose of meeting the need of foreign language learner. Many authentic samples of language used and conversed in real-life contexts are found in relevance to the proposition that language is a medium of expressing ideas in literature." Maru also states that "Literary text does not only provide useful extracts for foreign language learning but also serves learners with attractions and curiosity". (Maru, 2009). Literature is most commonly used to refer to works of the creative imagination, including works of fiction, nonfiction, poetry, and drama (Taylor, 1981: 12). And biographies are distinct from creative non-fiction such as memoir in that biographies are specifically about one person's full life story. (Nordquist, 2018)

Princess Diana is not only famous as a princess, but she is well-known for the humanitarian actions that she gives to the people, not only to the British society but also to the people in the world.

The writer is interested in discussing more about Princess Diana's life because most of millennial generations do not know who she is. Some people know her but only know she is a princess. The millennial do not know exactly who real
Diana is. A princess who has a different life with other princesses in the world at that time, Princess Diana taught many things about life and she has important role for society. Diana has a duty as a Princess by actively visiting a number of countries to carry out royal duties and as her role as a Princess, Diana is active in various social activities. Diana prefers to help people who need help by formed organizations and charities dedicated to the sick and needy. It is through her role that the duty as a Princess can have a positive impact on the society. What Diana had done before had never been done by other members of the royal family at that time. Through events that occurred in her life, and what she has done is the lesson for every human being. And her role still remains even though she is gone. She is an icon in life, a legend in death. Which is a shame to forget her, and it is a pity if people do not know her.

\section{RESEARCH METHODOLOGY}

The research writer uses a qualitative research. According to Bogdan and Biklen (1992), qualitative research is descriptive, they both assert that "Qualitative research is descriptive the data collected are in the form of words or picture rather than numbers, the written result of the research contains quotation to illustrate and substantie the presentation". In this research the writer uses two categories of sources, they can classify: primary and secondary sources. The data collected from the primary source of the Biography book; Diana: Her True Story In Her Own Words by Andrew Morton and the secondary source is other material that supports the analysis, such as a book 
and website. In analyzing data, the writer uses biographical approach. According to Christopher Russel Reaske (1966) stated that: Biographical approach examines the literary work in relation to someone's life. Or simply we can say, Biographical approach is an approach used to understand and comprehend a literary work by studying deeper about someone's life.

\section{FINDING AND DISSCUSSION}

The role of Diana in society as a humanitarian began after she became a Princess who married Prince Charles and became a member of royal family. Like the role of a princess who carries out royal duties by visiting various countries, that's where Diana begins to visit sick people and other needy people. Diana's desire to help people in need gets higher and makes her feel happy to help others.

Diana's role in society as a humanitarian includes her activities in the following matters:

\section{AIDS, Leprosy and Other Diseases}

Diana's attention to Aids sufferers is not just visiting and entertaining them. Diana gives more attention in the form of touch and embrace for them. Even Diana had broken the stigma about Aids by shook hands with Aids sufferers. It can be seen below:

"Remember, this was the same woman who in 1987 had done more than anyone alive to remove the stigma surrounding the deadly Aids virus when she shook the hand of terminally ill sufferer at London's Middlesex Hospital. While she was not able to fully articulate it, Diana had a humanitarian vision for herself. That transcended the dull, dutiful round of tradition royal engagements." (14)

From above quotation, explained that, Diana broke the stigma about Aids if shook hands or came into contact with Aids sufferers, but Diana proved by shook the hand of a person with Aids. Not only that, Diana also embraced and gave a hug. That can be seen below:

"As America's then First Lady, Barbara Bush, discovered when she joined the Princess on a visit to an Aids ward of the Middlesex Hospital in July 1991 there was nothing maudlin about Diana's attitude towards the sick. When a bed-bound patient burst into tears as the Princess was chatting to him, Diana spontaneously put her arms around him and gave him enormous hug. It was a touching moment which affected the First Lady and others who were present. While she spoke later of the need to give Aids sufferers a cuddle, for Diana this moment was a personal achievement. As she held him to her, she was her own self rather than conforming to her role as a princess." (259)

From above quotation tells that Diana visited aids patients with the United States first lady Laura Bush. Diana's desire to meet patients is to want to hug them. Diana chatted with one of the patients and comforted and hugged him. Diana felt comfortable with the patients and she didn't want to leave. She did it from herself not as a princess. It which meant the love she gave is sincere and does not look feathered. The sincerity of a 
Diana also in visiting the sufferers of Aids and cancer can be seen below:

"[On her work life] I still like to do what I call my 'Awaydays' once a week. [...] I'd change a few things in that I would go around hospices, Aids, cancer. I'd do that full time. I don't find it exhausting." (114)

From the above quotation tells that, her 'Awaydays' is when she visits hospitals, and visits AIDS sufferers and cancer. She spends her time with it. And she doesn't feel tired in visits and do that. It means that she did it all on her own heart not because of coercion and she did everything sincerely. Diana's involvement was not only in Aids but also in other diseases, such as leprosy, and people with eating disorders. It can be seen below:

"Her interest in women's issues was matched by her growing awareness that she could play a genuine solo role on her own upon the world stage. It was exciting and exhilarating. Her works for Aids and leprosy proved that she could cut across national boundaries while her courage in admitting her eating disorders had prompted thousands of sufferers around the world to seek help. Many sent her letters of gratitude for helping them face problem in their own lives." (380)

From the above quote it is concluded that Diana's success in help not only Aids sufferers and leprosy. Through the success of Diana struggling with eat disorders or bulimia, many fighters who experience the same thing as Diana got inspiration from Diana's story, so many succeeded in suffered the disease. In addition to shaking hands with AIDS sufferers, Princess Diana visited
Indonesia and visited lepers in Banten hospital, according to Kompasiana, Diana without fear and no disgust to shake hands with lepers, it can be seen below:

"In November 1989 Princess

Diana visited Indonesia. Princess Diana took the time to come to Sitanala Leprosy Hospital in Banten. Princess Diana then hesitantly sat in bed with lepers there. She also did not hesitate to shake hands with patients affected by leprosy who were treated at Sitanala Hospital. She also unhesitatingly touched the wound wrap bandage of the patient there."

From the quotation above, it is more clearly explained how Diana is truly active in the world of Humanitarianism, not to pretend and seek praise or formality, but Diana does it all through her sincere and with all her humbleness.

Diana's activity is visits people who are sick, suffering and who are struggling to survive. A Princess who is willing to entertain the sick people, she does not mind sitting together with the patient without mouth's mask or gloves, she even mingles with hospital patients in the lower-class. Diana's concern for health problem is one of Diana's did in her humanitarian activities.

\section{Human Welfare}

Diana's activity in her humanitarian activities is not just focus on the sicks. Diana also cares about human equality and welfare. One of the visits to Africa that Diana did was one of her campaigns to raise awareness of human welfare. That can be seen below:

"A photocall in the course of a visit to Zimbabwe in July, during which she was pictured doling out food to children, symbolized her 
deep dissatisfaction with the inane circus. She felt the exercise patronized the children and reinforced the 'begging-bowl' image of Africa. She vowed that it would never happen again." (354) From above quotation tells that at that time Diana visited Africa and passed one of Diana's photographs depicting Diana distributed the food. Diana feels that the children of Africa or the people of Africa are considered to be a poor people who are considered beggars and inferior. When Diana shared the food for the children of Africa, Diana's humility is very visible here. Diana's concern was also aimed at helping people who did not have a home or homeless. That can be seen below:

"I think I'm going to cut a very different path from everyone else. I'm going to break away from this set-up and go and help the man on the street. I hate saying 'man on the street' - it sound so condescending." (117)

From above quotation tells that in England at that time people who did not have a home or Homeless were usually called "man on the street" or street people. Diana was very displeased with the word that said "man on the street". Diana also took the time to visit the homeless and the people who experienced violence, she was active in doing that even though she was in problem of her marriage. It can be seen below:

"During the summer of 1992, when public attention on her marriage was at its most intense, she had begun a series of private visits to hospices, visits that resulted in her plan to one day open hundreds of such institutions around the world. At the same time she toured refuges for battered women and shelters for the homeless, as well as entertaining charity officials at Kensington Palace or joining them in a variety of discussion group." (360-361)

The quote above explains that Diana, despite in her marriage problems, remained active in her humanitarian activities by actively visiting people in need, including homeless people and women victims of violence. Diana also often invited her children to visit homeless shelters and patients at the hospital. It can be seen below:

"Over the years she took both boys on visits to hostel for the homeless and to see seriously ill people in hospital. [....] she took William on a secret visit to the Passage day centre for the homeless in Central London," (364)

From the quotation above, Diana invited and taught her two children to care for others, especially those in need. And that's where they are taught to care for others.

\section{Landmines}

In addition to focusing on health problems in the society and human welfare, Diana was also active in activities against land mines. It can be seen below: "...., her involvement with the landmine issue was a case of the right pitch at the right time. [...] Furthermore she decided to accompany Red Cross officials and a BBC film crew to publicize the work of the charity in war-torn Angola, it was, as Diana would have put it, a 'very grown-up' assignment. [....] More than that, 
by adding her weight to the campaign she clearly was making a difference. Pictures of her walking through a minefield in Angola forced the world to sit up and take notice - 'The impact she had was absolutely phenomenal,' said the British Red Cross. It became one of the most iconic photographs of her career. Enthused by this initial success the new British government responded by banning the export and use landmines while the Clinton administration was pressurized into a similar policy rethink." (383-384)

From the quote above, Diana's activities about landmines are phenomenal. Diana expressed concern about the land mines in Angola, Diana dared to take risks to fight for the fight against landmines. Diana's concerns and concerns were different from others where she dared to walk in areas with land mines, areas that were very dangerous. Through Diana's persistence in striving to ban landmines, the British government finally responded and banned the export of land mines, while the US government still responded and considered a return policy on landmines. Diana was very enthusiastic in the campaign against landmines. It can be seen below:

"Her enthusiastic focus on her humanitarian causes, notably her campaign against landmines, and the sense that she had resolved many of the difficulties that had assailed her since her departure from the royal family, were sources of quiet pleasure for many of her supporters." (400)
From the quote above explain that Diana's supporters were very pleased with Diana's success in her humanitarian activities, especially regarding landmines and the completion of her suffering in her household problems with Prince Charles. Diana's activities in humanitarian activities have been successful.

Diana's footsteps were followed by her son Prince Harry. Harry visited the place Diana had visited, it can be seen below:

"Thus, Harry visited minefields in Mozambique in 2010 and Angola in 2013 to see the work of HALO, the landmine clearance organization passionately backed by the late Princess. The image of her walking alone through a recently cleared minefield is one of most vivid representations of her humanitarian mission. For Harry the trip was very much a chance to follow in his mother's footsteps." (433)

From the above quote it can be concluded that even though she is gone, Diana's legacy of concern declined in her children including Harry who followed her previous footsteps, visited minefields in Mozambique and in Angola.

\section{Charities}

In order to help distressed and suffering people who need help, Diana formed several charities to fund the sick and needy. Diana's struggle in humanitarian activities, as well as making a charity event she did with her own business with the help of her secretary without interference from members of the royal family, but many Diana's charitable endeavors were successful. It can be seen below: 
"She and her private secretary, Patrick Jephson, began discreetly lobbying her many influential contacts on behalf of her charities. For a time, the Princess handled her own press relations, with mixed success.

None of this, however, not even the most fulfilling charity work or the most successful appeal, could hide the fact that Diana's life was in limbo." (365-366)

From the above quotation explained that Patrick Jephson as Diana's secretary helped Diana in a charity. Charities with Diana's involvement were quite successful but Diana's success was unable to cover up the problems that were happening to her at that time. At that time Diana was separated from Prince Charles but was not yet officially divorced, Diana was automatically a royal family. That is precisely what made Diana feel miserable because from the royal side no one supported her.

In addition, after divorce with Prince Charles, Diana donated her royal stuff for charity event, it can be seen below:

"Earlier that summer, her decision to sell her royal wardrobe at a charity auction in New York was a very public sign that the Princess was about move on, that her new life, her real life, was just beginning." (400)

The quote above tells that Diana donated her royal clothes to be auctioned off at a charity event. Although it is a valuable object, Diana chose to be donated to charity so that the results can be useful for others. This is also a form of Diana's actions to open her new life after divorce with Prince Charles. Not only are the stuffs of Diana had to donate, Diana's name is used in various kinds of charities in the world, and is used for hospitals as memories and inspiration for generations to live. It can be seen below:

"She has been garlanded with numerous posthumous awards the Nobel Peace Prize would have been particularly appropriate - her name has been lent to hospitals, hospices and other charitable causes around the world, while her work and memory continue to inspire any among this generation to live worthier and more fulfilled lives." (416)

From the quote above tells that Diana has many posthumous awards. Even though Diana is gone but her name is still there to help people. For example 'Diana' became the name of a charity organization and assistance even a hospital. This is also a sign that Diana's role in society is expanding. Even though Diana was gone, the charities and fundraising continued and increased.

\section{CONCLUSION}

After doing research to reveal how the role of Princess Diana in society, the writer found that in Diana's biography: Her True Story - In Her Own Words from Andrew Morton reveals and explains the roles of Princess Diana in society. The role of Princess Diana in the society describes as a humanitarian and because of her high social spirit in society she is referred to as "The People's Princess".

In the research, the writer found many explanations how the Princess' activity in humanitarian activities are helping people who are sick, helping people who are suffering, helping people in distress. Diana's actions managed to 
break the royal tradition where members of the royal family were considered too rigid in society and Diana proved it. She violated royal rules which she considered very different from herself that every member of the royal family was forbidden to give a handshake to the public, even to be in direct contact with ordinary people was a violation. But Diana did not follow the rules, she sincerely shook hands with anyone she met, even she visited sick people and gave them a kiss and a hug of affection. There is no limit whatsoever between Princess Diana and society. Princes Diana was very active in various activities, she was always seen visiting and entertaining AIDS sufferers, leprosy and other diseases, she also actively visited homeless people in shelters, she was active in supporting human welfare, and actively raised funds and formed charities to help people who need help

The one thing that Diana had done that shocked the world at the time was when she broke the stigma about Aids, that touching or shaking hands with people with Aids would get infected, but Diana shook their hands and even sat close and comforted them. Besides that which is not less great than that, Diana shakes hands with lepers without gloves. Diana also bravely walked in the area that was landed by landmines in protest of landmines in Angola. Diana also often entertained friends who were grieving or grieving even people she didn't even know if she knew they were sad and grieving she was willing to humbly entertain them. Telling about Diana's goodness is endless. Diana's role in society can be said to be perfect, but Diana is like people in the world, who are just ordinary people who have weaknesses and her life is far from perfect.
Even though the princess was gone but the legacy that she gave to her children, worthy lessons about the life she taught in her children made them follow in her mother's footsteps so Diana's role in society remains until now.

\section{BIBLIOGRAPHY}

Bogdan, Robert and Sari Knopp Biklen. Qualitative Research for Education $2^{\text {nd }}$ edition. Boston : Allyn and Bacon, Inc, 1992.

Denzin, Norman K. \& Lincolin, Yvonna S. Hanbook of Qualitatitave Research.Yogyakarta:Pustaka

Pelajar, 2009.

Gillin. John L. and John P. Gillin. Cultural Society. New York: Macmillan. 1948

Hallemann, Caroline. British Princess Royal Title Meaning. Townandcountrymag.com. Oct 5 2017. Web. Aug 222018. https://www.townandcountrymag.com/so ciety/tradition/a12775724/ british-princess-royal-titlemeaning/

Horton, Paul B. and Chester L. Hunt. Sociology (Sixth Edition). McGraw Hill Education, 2004.

Hookham, Jorgen. What does a Humanitarian do?. Sokanu.com. Web. 17 Oct 2018.

https://www.sokanu.com/careers/humanit arian/

Maru, Mister Gidion. Reconciling Literary Text with Learners' Trust in EFL Class

1.

Tondano, North Sulawesi : Manado State University, 2009. Maru, Mister Gidion. The Stereotype of American Upper Class Woman in the Late

JELLT (Journal of English Language and Literature Teaching)

Vol. 5 No. 02 November 2020

P.ISSN: 2548-7728 E.ISSN: 2599-0373 
Ninetenth Century (A Case Study of New York Woman in Wharton's The Age of Innocence). DIY: Lembah

Manah, 2014.

Melina, Remy. Difference Duchess and Princess. Livescience.com. May 252010.

Web. Aug $22 \quad 2018$. https://www.livescience.com/6523differenceduchess-princess.html

Morton, Andrew. Diana: Her True Story

- In Her Own Words. London: Michael O'Mara Books Ltd,

2017.

Noddings, Nel. Starting at Home: Caring and Social Policy. California: University of California, 2002.

Nordquist, Richard. Biographies: The Stories of Humanity. ThoughtCo, 29 Maret

2018. Web. 5 Juni 2018. https://www.thoughtco.com/what-isbiography1689170

Pinker, Robert A. Social service. Encyclopedia Britannica. July 312016. Web.

$$
\text { Aug } \quad 222018 .
$$

https://www.britannica.com/topic/socialservice

Reaske, Christopher R. How to Analyze Poetry. United States of America: Department of English Harvard University, 1966.

Soekanto, Soejono. Sosiologi Suatu Pengantar. Jakarta : Rajawali Pers, 2009

Soyomukti, Nurani. Pengantar Sosiologi : Dasar Analisis Teori, \& Pendekatan Menuju Analisis Masalah -Masalah Sosial, Perubahan Sosial, \& Kajian - Kajian Strategis. Yogyakarta : Ar - Ruzz Media, 2014.
Taylor, Richard. Understanding the Elements of Literature : Its Forms, Techniques and Cultural Conventions. New York : ST. Martin's Press, 1981.

The Royal House Hold. The Role of the Royal Family. Royal.uk. Wen. Sept 25 2018.

https://www.royal.uk/role-royal-family

Thompson, Rachel. How Princess Diana made the world pay attention to causes that actually needed it. MashableAsia. August 31 2017. Web. Oct 15

2018.

https://mashable.com/2017/08/31/princes s-diana-humanitarianwork/

Wellek, Rene and Austin Warren. Theory of Literature. Harmondsworth : Penguin Books, 1963.

Winstead, Vicky. C. Elements of Biography. Slideshare LinkedIn. 19 Agustus

2014.Web.5 Juni 2018.

https://www.slideshare.net/vcwinstead/el ements-

\begin{tabular}{lll}
\multicolumn{2}{c}{ of-biography } \\
Wolfman, Brunetta
\end{tabular} R. Roles.

